\title{
Photic zone changes in the north-west Pacific Ocean from MIS 4-5e
}

\author{
G. E. A. Swann ${ }^{1}$ and A. M. Snelling ${ }^{2}$ \\ ${ }^{1}$ School of Geography, University of Nottingham, University Park, Nottingham, NG7 2RD, UK \\ ${ }^{2}$ NERC Isotope Geosciences Facilities, British Geological Survey, Keyworth, Nottingham, NG12 5GG, UK
}

Correspondence to: G. E. A. Swann (george.swann@ nottingham.ac.uk)

Received: 11 August 2014 - Published in Clim. Past Discuss.: 29 August 2014

Revised: 26 November 2014 - Accepted: 27 November 2014 - Published: 6 January 2015

\begin{abstract}
In comparison to other sectors of the marine system, the palaeoceanography of the subarctic North Pacific Ocean is poorly constrained. New diatom isotope records of $\delta^{13} \mathrm{C}, \delta^{18} \mathrm{O}, \delta^{30} \mathrm{Si}\left(\delta^{13} \mathrm{C}_{\text {diatom }}, \delta^{18} \mathrm{O}_{\text {diatom }}\right.$, and $\left.\delta^{30} \mathrm{Si}_{\text {diatom }}\right)$ are presented alongside existing geochemical and isotope records to document changes in photic zone conditions, including nutrient supply and the efficiency of the soft-tissue biological pump, between Marine Isotope Stage (MIS) 4 and MIS 5e. Peaks in opal productivity in MIS 5b/c and MIS 5e are both associated with the breakdown of the regional halocline stratification and increased nutrient supply to the photic zone. Whereas the MIS 5e peak is associated with low rates of nutrient utilisation, the MIS $5 \mathrm{~b} / \mathrm{c}$ peak is associated with significantly higher rates of nutrient utilisation. Both peaks, together with other smaller increases in productivity in MIS 4 and $5 \mathrm{a}$, culminate with a significant increase in freshwater input which strengthens/re-establishes the halocline and limits further upwelling of sub-surface waters to the photic zone. Whilst $\delta^{30} \mathrm{Si}_{\text {diatom }}$ and previously published records of diatom $\delta^{15} \mathrm{~N}\left(\delta^{15} \mathrm{~N}_{\text {diatom }}\right)$ (Brunelle et al., 2007, 2010) show similar trends until the latter half of MIS 5a, the records become anti-correlated after this juncture and into MIS 4, suggesting a possible change in photic zone state such as may occur with a shift to iron or silicon limitation.
\end{abstract}

\section{Introduction}

The modern-day subarctic north-west Pacific Ocean represents a major component of the global oceanic system acting as the one of the terminuses of the deep water thermohaline circulation. Today high precipitation and low evaporation in the region maintain a year-round halocline in the water column (water depth $=100-150 \mathrm{~m}$ ), reinforced in the summer/early autumn months by the presence of a seasonal thermocline (water depth $=50 \mathrm{~m}$ ) (Emile-Geay et al., 2003; Antonov et al., 2010; Locarnini et al., 2010). This stratification exerts a major impact on the regional ocean by limiting the mixing of surface waters with underlying nutrientand carbon-rich deep water and by preventing convection and formation of North Pacific Deep Water (Emile-Geay et al., 2003; Menviel et al., 2012).

The initial development of the halocline and stratified water column has been attributed to the onset of major Northern Hemisphere glaciation (NHG) at $2.73 \mathrm{Ma}$, which increased the flux of freshwater to the region, via increased monsoonal rainfall and/or glacial meltwater, and sea surface temperatures (SSTs) (Sigman et al., 2004; Haug et al., 2005; Swann et al., 2006; Nie et al., 2008). The decrease of abyssal water upwelling associated with this may have contributed to the establishment of globally cooler conditions and the expansion of glaciers across the Northern Hemisphere from $2.73 \mathrm{Ma}$ (Haug et al., 2005). Whilst the halocline appears to have prevailed through the late Pliocene and early Quaternary glacial-interglacial cycles (Swann, 2010), other studies have shown that the stratification boundary may have broken down in the late Quaternary at glacial terminations and during the early part of interglacials (Sarnthein et al., 2004; Jaccard et al., 2005, 2009, 2010; Galbraith et al., 2007, 2008; Gebhardt et al., 2008; Brunelle et al., 2010; Kohfeld and Chase, 2011).

Developing a complete understanding of the nature of regional stratification in the subarctic North Pacific Ocean is important for a number of reasons. Firstly, the palaeoceanographic history of the region remains poorly constrained relative to other sectors of the global ocean. Secondly, with evidence of a pervasive link between the subarctic Pacific and Southern oceans (Haug et al., 2005; Jaccard et al., 2005, 
2010) records from the former can be used to further investigate teleconnections between these regions (Haug and Sigman, 2009; Sigman et al., 2010). Thirdly, with subsurface waters in the ocean interior rich in carbon and nutrients (Galbraith et al., 2007; Gebhardt et al., 2008; Menviel et al., 2012), any weakening/removal of the halocline has potential implications for the regional soft-tissue biological pump and ocean-atmospheric exchanges of $\mathrm{CO}_{2}$.

To further understand the subarctic north-west Pacific Ocean, diatom isotope measurements of $\delta^{13} \mathrm{C}, \delta^{18} \mathrm{O}, \delta^{30} \mathrm{Si}$ $\left(\delta^{13} \mathrm{C}_{\text {diatom }}, \delta^{18} \mathrm{O}_{\text {diatom }}\right.$, and $\left.\delta^{30} \mathrm{Si}_{\text {diatom }}\right)$ are presented here from the open waters of ODP Site 882 between Marine Isotope Stage (MIS) 4 and MIS 5e (Fig. 1). Existing research from the region has revealed two periods of elevated opal concentration in this interval alongside large changes in proxies relating to nutrient supply and utilisation (Jaccard et al., 2005, 2009; Brunelle et al., 2007, 2010). The new diatom isotope data presented here will allow the changes in photic zone conditions and the response of the soft-tissue biological pump to be further constrained. Diatoms, unicellular siliceous algae, are ideally suited for this purpose as they (1) occupy the uppermost sections of the water column above the halocline, (2) dominate export production in high-latitude and upwelling zones (Nelson et al., 1995), and (3) represent a key component of the soft-tissue biological pump in transferring carbon into the ocean interior by incorporating ca. $23.5 \%$ of all carbon produced by net primary production into their cellular organic matter (Mann, 1999).

\section{Methods}

ODP Site 882 is located on the western section of the Detroit Seamounts at a water depth of $3244 \mathrm{~m}\left(50^{\circ} 22^{\prime} \mathrm{N}\right.$, $167^{\circ} 36^{\prime} \mathrm{E}$ ) (Fig. 1). The age model used in this study is derived from the astronomical calibration of high-resolution GRAPE density and magnetic susceptibility measurements with linear interpolation between selected tie points (Jaccard et al., 2009). Ages are constrained by two radiocarbon dates and verified by correlating magnetic susceptibility and benthic foraminifera $\delta^{18} \mathrm{O}$ records from ODP Sites 882 and 883 . Samples were prepared for diatom isotope analysis using techniques previously employed at this site (Swann et al., 2006, 2008) with the $75-150 \mu \mathrm{m}$ fraction analysed. Diatom biovolumes, calculated following Hillebrand et al. (1999) and Swann et al. (2008), show that samples in this fraction are dominated by a single taxa Coscinodiscus radiatus (Ehrenb.) (Fig. 2) which blooms throughout the year with elevated fluxes often occurring in autumn/early winter (Takahashi, 1986; Takahashi et al., 1996; Onodera et al., 2005). Consequently, the diatom isotope measurements obtained here are interpreted as primarily reflecting annually averaged conditions with a slight bias towards autumn/early winter months. Smaller size fractions which contain a greater diversity of taxa were not analysed due to the potential for

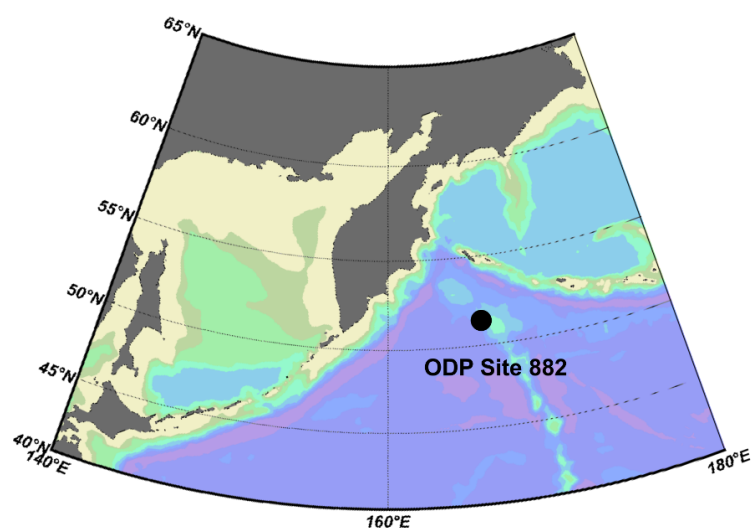

Figure 1. Location of ODP Site 882 in the subarctic north-west Pacific Ocean.

vital effects in $\delta^{18} \mathrm{O}_{\text {diatom }}$ (Swann et al., 2008). Sample purity was assessed for all samples using light microscopy and SEM with unclean samples disregarded for isotope analysis. Both techniques show the excellent preservation of diatoms in the sediment record and suggest that issues of dissolution/diagenesis are not relevant to this study.

$\delta^{18} \mathrm{O}_{\text {diatom }}$ and $\delta^{30} \mathrm{Si}_{\text {diatom }}$ were analysed following a combined step-wise fluorination procedure at the NERC Isotope Geoscience Laboratory (UK) (Leng and Sloane, 2008) with measurements made on a Finnigan MAT 253 and values converted to the VSMOW and NBS28 scale respectively using the NIGL within-run laboratory diatom standard $\mathrm{BFC}_{\text {mod }}$ which has been calibrated against NBS28. A small subset of the $\delta^{18} \mathrm{O}_{\text {diatom }}$ data was previously published as part of

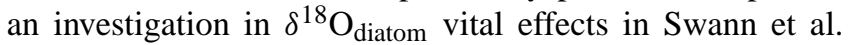
(2008) (see Table S1 in the Supplement). Where sufficient material remained following $\delta^{18} \mathrm{O}_{\text {diatom }}$ and $\delta^{30} \mathrm{Si}_{\text {diatom }}$ analysis, samples were analysed for $\delta^{13} \mathrm{C}_{\text {diatom }}$ using a Costech elemental analyser linked to an Optima mass spectrometer via cold trapping (Hurrell et al., 2011). Replicate analyses of sample material across the analysed interval indicate an analytical reproducibility $(1 \sigma)$ of $0.4 \%, 0.06 \%$ and $0.3 \%$ for $\delta^{18} \mathrm{O}_{\text {diatom }}, \delta^{30} \mathrm{Si}_{\text {diatom }}$ and $\delta^{13} \mathrm{C}_{\text {diatom }}$ respectively.

\section{Results}

Through the analysed interval, $\delta^{13} \mathrm{C}_{\text {diatom }}$ largely follows previously published siliceous productivity (opal) records from the region in indicating two intervals of higher productivity from 130 to $114 \mathrm{kaBP}$ (MIS 5e) and from 101 to $86 \mathrm{kaBP}$ (MIS 5b/c) (Jaccard et al., 2005, 2009) (Fig. 3). Before/after each of these intervals $\delta^{13} \mathrm{C}_{\text {diatom }}$ is lower at $<-18 \%$. These trends are also largely mirrored by the $\delta^{30} \mathrm{Si}_{\text {diatom }}$ and $\delta^{15} \mathrm{~N}$ records of diatom-bound nitrogen $\left(\delta^{15} \mathrm{~N}_{\text {diatom }}\right)$ (Brunelle et al., 2007, 2010) records of nutrient supply/utilisation, except during MIS 5e when values for both remain low and comparable to those in MIS 5d (Fig. 3). 


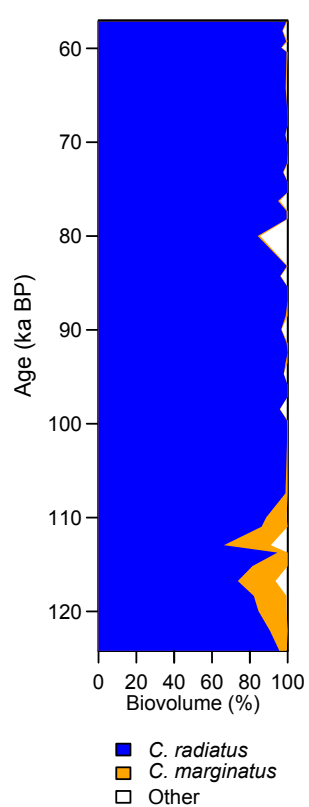

Figure 2. Relative diatom species biovolumes in samples analysed for $\delta^{18} \mathrm{O}_{\text {diatom. }}$.

Following a return to lower values in MIS 5a, all productivity/nutrient proxies show a series of abrupt oscillations that continue into MIS 4 with values in this interval equivalent to the peaks and minima documented in MIS $5 \mathrm{~b}-\mathrm{e}$.

Measurements of $\delta^{18} \mathrm{O}_{\text {diatom }}$ can be classified into three stages: (1) periods of relative stability in MIS 5e and MIS $5 \mathrm{~b} / \mathrm{c}$ (124-114 and 102-87 kaBP), (2) periods of significant decreases $(\geq 4 \%$ o) in MIS 5d and MIS 5a (113-100 and $85-76 \mathrm{kaBP}$ ), and (3) periods of increase variability in MIS 5a-4 (75-57 kaBP) (Fig. 3). Intervals of high and stable $\delta^{18} \mathrm{O}_{\text {diatom }}$ values in MIS 5e and MIS 5b/c coincide with peaks in $\delta^{13} \mathrm{C}_{\text {diatom }}$ and opal concentrations. The termination of both productivity phases, as indicated by changes in $\delta^{13} \mathrm{C}_{\text {diatom }}, \delta^{15} \mathrm{~N}_{\text {diatom }}, \delta^{30} \mathrm{Si}_{\text {diatom }}$ and opal concentrations, are then concordant with the large reductions in $\delta^{18} \mathrm{O}_{\text {diatom }}$ during MIS $5 \mathrm{~d}$ and MIS 5a, suggesting a link between the processes controlling $\delta^{18} \mathrm{O}_{\text {diatom }}$ and photic zone productivity/nutrient utilisation. This is reinforced by the often synchronous changes between $\delta^{18} \mathrm{O}_{\text {diatom }}, \delta^{30} \mathrm{Si}_{\text {diatom }}$ and opal concentrations during MIS 5a and into MIS 4.

\section{Discussion}

\subsection{Environmental controls on diatom isotopes}

Given the limited number of published diatom isotope records in palaeoceanography, the section below summarises the main controls on $\delta^{18} \mathrm{O}_{\text {diatom, }} \delta^{30} \mathrm{Si}_{\text {diatom }}$ and $\delta^{13} \mathrm{C}_{\text {diatom. }}$. Diatom isotopes act as an alternative proxy to records from planktonic foraminifera at sites, such as ODP Site 882, depleted in carbonates. Measurements of $\delta^{18} \mathrm{O}_{\text {diatom }}$ can be in- terpreted in the same way as those of planktonic foraminifera $\left(\delta^{18} \mathrm{O}_{\text {foram }}\right)$ (Swann and Leng, 2009) with variations linked to changes in temperature $\left(-0.2 \% 0^{\circ} \mathrm{C}^{-1}\right)$ (Brandriss et al., 1998; Moschen et al., 2005; Dodd and Sharp, 2010; Crespin et al., 2010) and surface water $\delta^{18} \mathrm{O}\left(\delta^{18} \mathrm{O}_{\text {water }}\right)$. During biomineralisation diatoms uptake silicon, in the form of silicic acid $\left(\mathrm{H}_{4} \mathrm{SiO}_{4}\right)$, with the lighter ${ }^{28} \mathrm{Si}$ preferentially used over ${ }^{29} \mathrm{Si}$ and ${ }^{30} \mathrm{Si}$. With an enrichment factor independent of temperature, the concentrations of $\mathrm{CO}_{2}$ in the water $\left(p \mathrm{CO}_{2(\mathrm{aq})}\right)$ and other vital effects (De La Rocha et al., 1997; Milligan et al., 2004), $\delta^{30} \mathrm{Si}_{\text {diatom }}$ reflects changes in photic zone silicic acid utilisation which is regulated by the biological demand for silicic acid, the rate at which nutrients are supplied to the photic zone and the $\delta^{30} \mathrm{Si}$ composition of the silicic acid substrate $\left(\delta^{30} \mathrm{Si}_{\mathrm{DSi}}\right)$ (De La Rocha, 2006; Reynolds et al., 2006).

A number of studies have examined the controls on $\delta^{13} \mathrm{C}_{\text {diatom }}$ on carbon from bulk cellular diatom organic material including the cytoplasm. Whilst palaeoenvironmental reconstructions solely analyse the cell wall, which is preserved in the sediment and protected from dissolution by the diatom frustule (Abramson et al., 2009), it is assumed that the controls on cell wall $\delta^{13} \mathrm{C}_{\text {diatom }}$ are similar to those for bulk ${ }^{13} \mathrm{C}_{\text {diatom }}$ as the cell-wall organic matter forms a key template for diatom biomineralisation (Hecky et al., 1973; Swift and Wheeler, 1992; Kröger et al., 1999; Sumper et al., 2004). During photosynthesis, organic carbon matter is formed from both $\mathrm{HCO}_{3}^{-}$and $\mathrm{CO}_{2 \text { (aq) }}$ (Tortell et al., 1997) using both active and indirect transportation mechanisms (Sültemeyer et al., 1993) and $C_{3}$ and $C_{4}$ photosynthetic pathways (Reinfelder et al., 2000). Marine studies including those from the Bering Sea and North Pacific Ocean have demonstrated that the majority of diatom carbon originates from $\mathrm{HCO}_{3}^{-}$ via direct transportation (Tortell and Morel, 2002; Cassar et al., 2004; Martin and Tortell, 2006; Tortell et al., 2006, 2008). Although $\mathrm{HCO}_{3}^{-}: \mathrm{CO}_{2}$ (aq) uptake ratios may alter with inter-species variations in cell morphologies (Martin and Tortell, 2008), no link exists with changes in $p \mathrm{CO}_{2}$ (aq), $\mathrm{Fe}$ availability, growth rates, primary productivity or frustule area : volume ratios (Cassar et al., 2004; Martin and Tortell, 2006; Tortell et al., 2006, 2008).

With ${ }^{12} \mathrm{C}$ preferentially fractionated over ${ }^{13} \mathrm{C}$ (Laws et al., 1995), $\delta^{13} \mathrm{C}_{\text {diatom }}$ predominantly reflects changes in photosynthetic carbon demand driven by variations in biological productivity or carbon cellular concentrations. Smaller magnitude variations in $\delta^{13} \mathrm{C}_{\text {diatom }}$ may then arise with changes in the composition of the dissolved inorganic carbon substrate $\left(\delta^{13} \mathrm{C}_{\mathrm{DIC}}\right)$ and through the intracellular and extra-cellular balance of $\mathrm{CO}_{2}$ with an increase in photic zone $p \mathrm{CO}_{2}$ (aq) reducing $\delta^{13} \mathrm{C}_{\text {diatom }}$ (Laws et al., 1995; Rau et al., 1996, 1997). Whilst questions remain over the potential for $\delta^{13} \mathrm{C}_{\text {diatom }}$ to be impacted by changes in $\mathrm{HCO}_{3}^{-}: \mathrm{CO}_{2}$ uptake, growth rates, amino acid composition, cell morphology as well as the diffusion of carbon into the cell by the enzyme RuBisCO (Laws et al., 1995, 1997, 2002; Rau et al., 1996, 


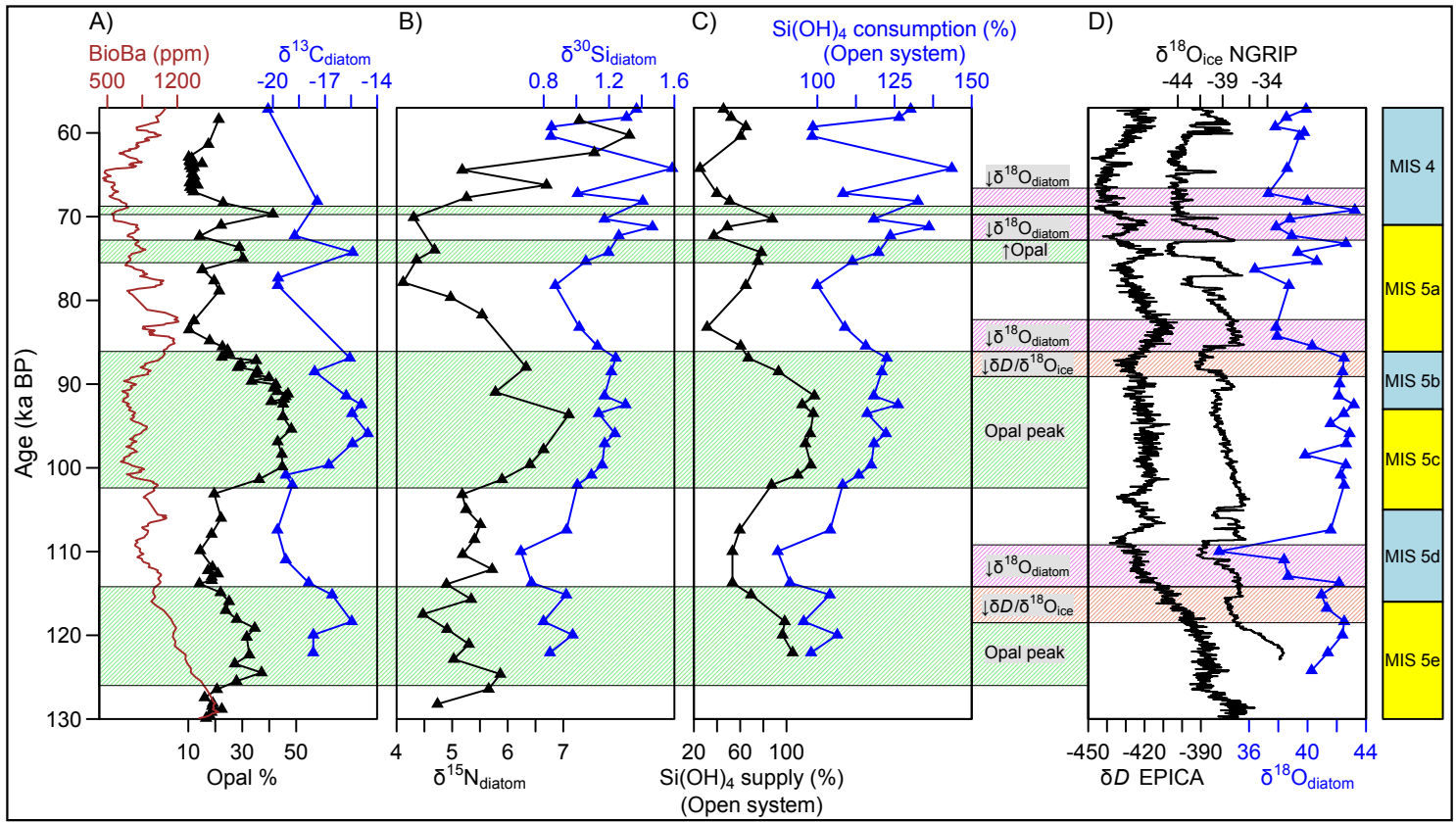

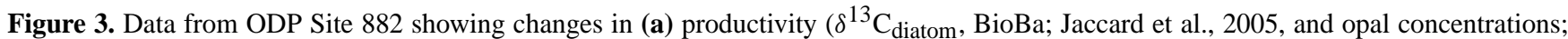
Jaccard et al., 2009); (b) nutrient dynamics $\left(\delta^{30} \mathrm{Si}_{\text {diatom }}\right.$ and $\delta^{15} \mathrm{~N}_{\text {diatom }}$; Brunelle et al., 2010); (c) modelled Si(OH) 4 supply/consumption in an open system model; and (d) freshwater input $\left(\delta^{18} \mathrm{O}_{\text {diatom }}\right)$ together with EPICA Antarctic $\delta$ D (Jouzel et al., 2007) and NGRIP Greenland $\delta^{18} \mathrm{O}_{\text {ice }}$ (NGRIP, 2004). Changes in the supply/consumption of $\mathrm{Si}(\mathrm{OH})_{4}$ are relative to mean conditions in MIS 5e. Green/red shading indicates the increases in productivity and decreases in $\delta^{18} \mathrm{O}_{\text {diatom }}$ respectively, which are discussed in the text.

1997, 2001; Popp et al., 1998; Cassar et al., 2006), many of these physiological processes as well as the impact of inter-species vital effects (Jacot des Combes et al., 2008) can be partially circumvented by analysing samples comprised of a single taxa. Consequently, with samples in this studies overwhelmingly dominated by $C$. radiatus, changes in $\delta^{13} \mathrm{C}_{\text {diatom }}$ are primarily interpreted as reflecting changes in photic zone productivity (Fig. 2). We argue that the impact of a changes in $\delta^{13} \mathrm{C}_{\text {DIC }}$ is negligible due to the aforementioned evidence that $\delta^{13} \mathrm{C}_{\mathrm{DIC}}$ exerts only a minimal impact on $\delta^{13} \mathrm{C}_{\text {diatom, likely within analytical error, although }}$ the lack of carbonates in the sediments prevents an independent $\delta^{13} \mathrm{C}$ record being established to prove this beyond doubt. Similarly we argue that higher $\delta^{13} \mathrm{C}_{\text {diatom }}$ values in MIS 5e, when higher $p \mathrm{CO}_{2}$ (aq) should have acted to reduce $\delta^{13} \mathrm{C}_{\text {diatom, }}$, point towards $p \mathrm{CO}_{2}$ (aq) not exerting a significant control on $\delta^{13} \mathrm{C}_{\text {diatom }}$, although we are aware of the circular reasoning with this argument.

\subsection{Changes in the regional biological pump (MIS 5e to MIS 5b)}

Previously published opal concentration data (Jaccard et al., 2009) together with $\delta^{13} C_{\text {diatom }}$ data from this study indicates two intervals of high siliceous productivity at ODP Site 882 through the analysed interval: the first from 130 to $114 \mathrm{kaBP}$ corresponding to the last interglacial (MIS 5e:
$130-116 \mathrm{kaBP})$, the second from 101 to $86 \mathrm{kaBP}$ covering the latter half of MIS 5c (105-93 kaBP) and most of MIS 5b (93-86 ka BP) (Jaccard et al., 2009) (Fig. 3, green shading). Whilst records of biogenic barium (BioBa) capture the MIS 5e peak (Jaccard et al., 2009), they fail to do so with the second flux event. Modern day calibrations have noted the lack of a relationship between BioBa and export production in the region (Serno et al., 2014) and speculated that the mismatch can be attributed to early diagenetic remobilisation of barium following a change in redox state (Gebhardt et al., 2008). On the other hand, all evidence points against an actual preservation/dissolution issue in this BioBa record (see Jaccard et al., 2009) and so, in line with Jaccard et al. (2009), we interpret $\mathrm{BioBa}$ as a measure of organic carbon export rather than siliceous productivity. With the isotope records reported here derived from diatoms and the siliceous fraction of the sediment record, we focus our discussion on the opal siliceous productivity record and only used BioBa as a proxy of organic carbon export.

Similar to the Southern Ocean, the modern-day subarctic north-west Pacific Ocean photic zone is largely limited by iron availability (Harrison et al., 2009; Tsuda et al., 2003). Accordingly, increases in bioavailable iron represent a plausible mechanism for explaining the two main (opal inferred) productivity peaks during MIS 5. Today iron supply is thought to primarily occur via aeolian dust deposition originating from East Asia and the Badain Juran Desert 
(Yuan and Zhang, 2006) and other global regions (Hsu et al., 2012). Additional iron is then derived from volcanic activity (Banse and English, 1999), continental margins (Lam and Bishop, 2008), advection of waters from the Okhotsk Sea (Nishioka et al., 2007) and winter mixing of surface/subsurface water (Shigemitsu et al., 2012). Both productivity peaks occur without a corresponding increase in aeolian dust at "Station 3" (close to ODP Site 882 at $50^{\circ} 00^{\prime} \mathrm{N}, 164^{\circ} 59^{\prime} \mathrm{E}$ ) (Shigemitsu et al., 2007) or in East Asian winter monsoon records from the Chinese Loess Plateau and other marine sites (Sun et al., 2006; Zhang et al., 2009). Whilst a doubling in aeolian dust does occur at "Station 3" during the early stages of MIS 5c, this ceases before any increase in

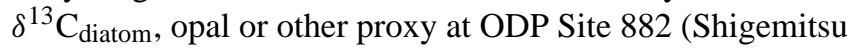
et al., 2007). The absence of a significant increase in bioavailable iron would appear to rule out a major role for iron in driving the two productivity peaks in MIS 5e and MIS 5b/c. This would be in line with evidence indicating that productivity peaks during the last deglaciation across the North Pacific Ocean also occur without a corresponding increase in aeolian dust or other iron source input (Kohfeld and Chase, 2011). Others have also argued that iron only exerts a secondary or minor control on regional water column productivity in the palaeo-record (Kienast et al., 2004; Lam et al., 2013) whilst we are unable to account for possible changes in the flux of bioavailable iron from the Okhotsk Sea, winter mixing and other sources identified above.

\subsubsection{Nutrient utilisation and supply}

The deep and intermediate waters of the subarctic North Pacific Ocean contain some of the highest nutrient levels in the world (Whitney et al., 2013). Accordingly productivity peaks over glacial-interglacial cycles, including those covered in this study, have been linked to changes in the regional halocline and water column stratification which would alter the advection of nutrient- and carbon-rich sub-surface waters into the photic zone (Jaccard et al., 2005; Gebhardt et al., 2008). A key difference between the two productivity events in MIS 5e and MIS 5b/c is the response of the biological community to raised photic zone nutrient availability. Although productivity is high during MIS 5e, values are low for $\delta^{30} \mathrm{Si}_{\text {diatom }}$ at ODP Site $882(<1.0 \%, n=$ $3)$ and for $\delta^{15} \mathrm{~N}_{\text {diatom }}\left(<6 \%\right.$ ) at a nearby site $\left(49^{\circ} 72^{\prime} \mathrm{N}\right.$, $168^{\circ} 30^{\prime} \mathrm{E}$ ) (Brunelle et al., 2010) (Fig. 3). In contrast during MIS $5 \mathrm{~b} / \mathrm{c}$ the productivity peak is concordant with an increase in $\delta^{30} \mathrm{Si}_{\text {diatom }}$ and $\delta^{15} \mathrm{~N}_{\text {diatom }}$ to ca. $1.2-1.3 \%$ and $>6 \%$ respectively (Fig. 3).

Changes in $\delta^{30} \mathrm{Si}_{\text {diatom }}$ may reflect either increased biological uptake of silicic acid (consumption) and/or changes in the supply of silicic acid to the photic zone. The modernday regional stratified water column is best represented by a closed system model in which a finite amount of silicic acid exists for biomineralisation (Reynolds et al., 2006). In contrast an unstratified water column would be reflected by an open system model with continual supply of silicic acid. By assuming that the two productivity peaks reflect a weakening in the stratification, an open system model can be used to investigate the controls on $\delta^{30} \mathrm{Si}_{\text {diatom: }}$

$\delta^{30} \mathrm{Si}_{\text {diatom }}=\delta^{30} \mathrm{Si}(\mathrm{OH})_{4}+\epsilon \cdot f$,

where $\delta^{30} \mathrm{Si}(\mathrm{OH})_{4}$ is the isotopic composition of dissolved silicic acid supplied to the photic zone, $\epsilon$ is the enrichment factor between diatoms and dissolved silicic acid and $f$ is the fraction of utilised $\mathrm{Si}(\mathrm{OH})_{4}$ remaining in the water. Existing work from the North Pacific Ocean has estimated $\delta^{30} \mathrm{Si}(\mathrm{OH})_{4}$ at $1.23 \%$ and $\epsilon$ as 1.0 (Reynolds et al., 2006). Using changes in $\mathrm{Si}(\mathrm{OH})_{4}$ consumption (Eq. 1) and siliceous productivity (opal), the supply of $\mathrm{Si}(\mathrm{OH})_{4}$ into the photic zone can be constrained relative to mean conditions during MIS 5e as

$\mathrm{Si}(\mathrm{OH})_{4 \text { supply }}=\frac{\mathrm{Opal}_{\text {sample }} / \mathrm{Opal}_{\mathrm{MIS} 5 \mathrm{e}}}{\left(1-f_{\text {consumed }}^{\text {sample }}\right) /\left(1-f_{\text {consumed }}^{\text {MIS 5e }}\right)}$.

Estimates of $\mathrm{Si}(\mathrm{OH})_{4}$ consumption and supply from Eqs. (1) and (2) are only applicable for intervals when the water column represents an open system (e.g. the productivity peaks in MIS 5e and MIS 5b/c) and are dependant on modern-day estimates of $\delta^{30} \mathrm{Si}(\mathrm{OH})_{4}$ being representative of past conditions. This assumption is based on evidence that $\delta^{30} \mathrm{Si}(\mathrm{OH})_{4}$ is relatively resilient to change, outside of seasonal biological fluxes, over timescales similar to this study except in extreme circumstances linked to major reductions in the flux of riverine silicon into the ocean (Rocha and Bickle, 2005). The results show that the productivity peaks in MIS 5e and MIS 5b/c are both closely correlated with elevated levels of $\mathrm{Si}(\mathrm{OH})_{4}$ being supplied to the photic zone (Fig. 3), supporting the suggestion that these intervals are linked to a reduction in water column stratification and an increase in the vertical flux of nutrients bearing sub-surface waters into the photic zone (Jaccard et al., 2005; Gebhardt et al., 2008). However, whilst the increase in $\mathrm{Si}(\mathrm{OH})_{4}$ supply in MIS 5b/c is matched by a corresponding increase in biological consumption of $\mathrm{Si}(\mathrm{OH})_{4}$, increasing the ratio of regenerated to preformed nutrients in the ocean interior, the opposite occurs during MIS 5e when the rates of $\mathrm{Si}(\mathrm{OH})_{4}$ consumption are at their lowest over the analysed interval. (Fig. 3). Whilst reduced $\mathrm{Si}(\mathrm{OH})_{4}$ consumption during MIS 5e could be linked to iron limitation, records indicate that aeolian dust deposition was equally low during both the MIS 5e and the MIS $5 \mathrm{~b} / \mathrm{c}$ productivity peaks. However, as before we are unable to account for changes in iron supply from non-aeolian sources.

\subsubsection{Implications for $p \mathrm{CO}_{2}$}

Understanding the mechanisms that regulate changes in atmospheric concentrations of $\mathrm{CO}_{2}\left(p \mathrm{CO}_{2}\right)$ remains a key objective in palaeoclimatology. Previous research has demonstrated that the Southern Ocean and low-latitude oceans 
act as the dominant source/sink of atmospheric $\mathrm{CO}_{2}$ over glacial-interglacial cycles (Pichevin et al., 2009; Fischer et al., 2010; Sigman et al., 2010). Whilst the North Pacific Ocean does not need to be invoked to explain the full amplitude of glacial-interglacial changes, recent work has advocated a potential role for the region in regulating atmospheric $p \mathrm{CO}_{2}$ over the last termination (Rae et al., 2014).

Today the net annual ocean-atmosphere exchange of $\mathrm{CO}_{2}$ in the subarctic north-west Pacific Ocean is close to zero, but alters from being a sink of atmosphere $\mathrm{CO}_{2}$ in spring to a source in winter (Takahashi et al., 2006; Ayers and Lozier, 2012) (Fig. 4a). This seasonal variability can be attributed to changes in the biological pump and in SST which affects the solubility of $\mathrm{CO}_{2}$ (Honda et al., 2002; Chierici et al., 2006; Ayers and Lozier, 2012). A weakening of the halocline stratification in MIS 5e and MIS 5b/c would have increased the advection of nutrient- and carbon-rich waters from the ocean interior, raising photic zone $p \mathrm{CO}_{2}(\mathrm{aq})$ and the potential for $\mathrm{CO}_{2}$ to be ventilated into the atmosphere due to an air-sea disequilibrium in $\mathrm{CO}_{2}$. This, however, is dependant on the response and relative efficiency of the biological pump in taking advantage of the increased nutrient supply and altering the ratio of regenerated : performed nutrients to re-export carbon into the deep ocean (Sigman et al., 2004, 2010; Marinov et al., 2008). Whilst changes in the temperature/thermocline may also have been important, the only SST record for the region (Martínez-Garcia et al., 2010) does not contain the temporal resolution to investigate this further and does not provide a surface-subsurface depth temperature transect.

During MIS 5e a scenario of both higher $p \mathrm{CO}_{2}(\mathrm{aq})$ and incomplete/low rates of nutrient utilisation suggests the regional ocean could have ventilated $\mathrm{CO}_{2}$ into the atmosphere faster than the soft-tissue biological pump reabsorbed and sequestered $\mathrm{CO}_{2}$ into the deep ocean (Fig. 4b) despite evidence for higher organic carbon export (BioBa) in this period (Fig. 3). The culmination of this interval at the end of MIS 5e would have resulted in the system returning to a stratified state, perhaps similar to the modern-day water column (Fig. 4a) with minimal air-sea fluxes of $\mathrm{CO}_{2}$. In contrast the opal productivity peak in MIS $5 \mathrm{~b} / \mathrm{c}$ is marked by similar levels of photic zone $\mathrm{Si}(\mathrm{OH})_{4}$ supply as in MIS 5 e but with ca. $20 \%$ higher rates of $\mathrm{Si}(\mathrm{OH})_{4}$ consumption (Figs. 3 and 4c). The combination of high siliceous productivity (opal $/ \delta^{13} \mathrm{C}_{\text {diatom }}$ ) and a highly efficient biological pump $\left(\delta^{30} \mathrm{Si}_{\text {diatom }} / \delta^{15} \mathrm{~N}_{\text {diatom }}\right)$ during this interval suggests that the net flux of ocean-atmosphere $\mathrm{CO}_{2}$ exchanges arising from the sea-air disequilibrium could have remained close to zero if photosynthetic carbon demand were similar to the rate of sub-surface carbon flux to the photic zone. Whilst a highly efficient soft-tissue biological pump raises the possibility for the region to have acted as a net sink of atmospheric $\mathrm{CO}_{2}$, the potential and significance for this is limited by the relatively low proportion of surface waters which reach the deep ocean interior (Gebbie and Huybers, 2011) and low BioBa in this interval (Fig. 3).

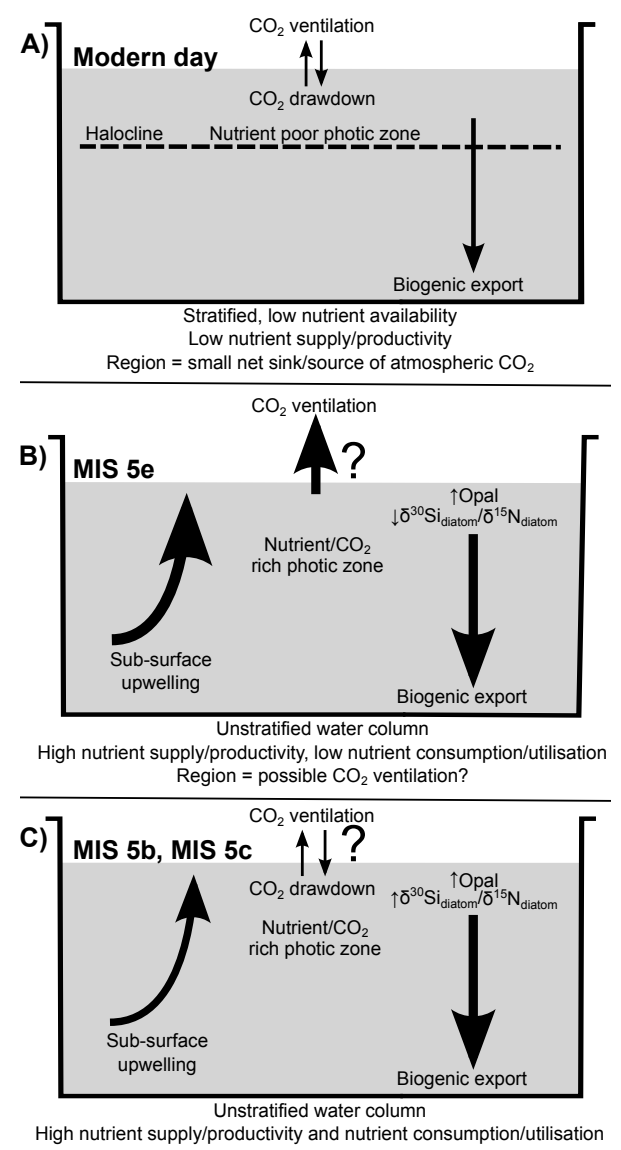

Region $=$ small source/sink of atmospheric $\mathrm{CO}_{2}$ ?

Figure 4. Schematic models showing subarctic north-west Pacific Ocean conditions for (a) modern day: halocline water column with nutrient poor surface waters limiting biological export; (b) MIS 5e: no halocline and enhanced upwelling of nutrient- and carbon-rich sub-surface waters leading to increased productivity. Low rates of nutrient utilisation suggest a possible increase in $\mathrm{pCO}_{2}$ and release of $\mathrm{CO}_{2}$ to the atmosphere; (c) MIS 5b/c: conditions similar to MIS $5 \mathrm{e}$ but with higher rates of nutrient consumption and a more efficient soft-tissue biological pump limiting/preventing ventilation of $\mathrm{CO}_{2}$.

Although the data suggest that changes in the regional photic zone may have contributed to variations in atmospheric $p \mathrm{CO}_{2}$ during MIS 5, both via the soft-tissue biological pump and associated changes in ocean alkalinity, it is not possible to quantify the magnitude of any fluxes or access whether they were accompanied by a change in diatom silicification and cellular $\mathrm{Si}: \mathrm{C}$ ratios. Firstly, insufficient purified diatom material remains to measure diatom silicon concentrations. Secondly, although diatom elemental carbon measurements obtained during the analysis of $\delta^{13} \mathrm{C}_{\text {diatom }}$ increase from $<0.3 \mathrm{wt} \%$ in MIS 5e to ca. 0.4 wt\% in MIS 5b-d (see Supplement Table S1), the analytical reproducibility for $\mathrm{C}_{\text {diatom }}$ is relatively high at $0.1 \%(1 \sigma)$ (Hurrell et al., 2011) and measurements are derived from the cell wall material and not the bulk cellular matter formed 
duringphotosynthesis. Furthermore, whilst other cores from the region show a similar double peak in opal productivity during MIS 5 (Narita et al., 2002) records at other sites suggest that the second peak is restricted to MIS $5 b$ with no increase in MIS 5c (Shigemitsu et al., 2007). Such discrepancies either suggest poor stratigraphic controls on the age model for either core, or the potential for significant spatial variability across the region and reiterates that the magnitude of any ocean-atmosphere fluxes of $\mathrm{CO}_{2}$ would be low compared to those occurring elsewhere in the marine system such as the Southern Ocean and low-latitude oceans.

\subsubsection{Freshwater controls on siliceous productivity}

Records show that the decline in siliceous productivity for both intervals culminates with large decreases in $\delta^{18} \mathrm{O}_{\text {diatom }}$ of ca. 3-5\% from ca. $113 \mathrm{kaBP}$ and $85 \mathrm{kaBP}$ (Fig. 3, red shading). The magnitude of change is too large to be driven by reductions in deep water upwelling or shifts in ocean water masses from both higher and lower latitudes, which would only alter $\delta^{18} \mathrm{O}_{\text {water }}$ by ca. $1 \%$ (LeGrande and Schmidt, 2006). Instead the drop in $\delta^{18} \mathrm{O}_{\text {diatom }}$ suggests an input of isotopically depleted freshwater that may be similar in origin to events documented at the same site during the late Pliocene/early Quaternary (Swann, 2010).

Although the modern-day regional halocline is maintained by high precipitation and low evaporation (Emile-Geay et al., 2003), it is difficult to envisage a sufficient increase in precipitation to initiate a $3-5 \%$ decrease in $\delta^{18} \mathrm{O}_{\text {diatom. }}$. This is reiterated by evidence that monsoonal activity was largely stable during MIS 5b-e (Sun et al., 2006; Zhang et al., 2009). At the same time the potential for a glacial source is questioned by evidence indicating a restricted glaciation in north-east Russia, closest to ODP Site 882, at the Last Glacial Maximum (LGM) (Barr and Clark, 2011, 2012), although other work suggests these ice sheets may have been considerably larger prior to the LGM (Bigg et al., 2008; Barr and Solomina, 2014). Recent work has shown that both of the major decreases in $\delta^{18} \mathrm{O}_{\text {diatom }}$ coincide with increases in IRD accumulation in some, but not all, cores from the Okhotsk Sea (Nürnberg et al., 2011). It has also been argued that the regional water column was regulated by significant inputs of meltwater from the North American ice sheets during the last deglaciation (Lam et al., 2013). In either case, the decrease in $\delta^{18} \mathrm{O}_{\text {diatom }}$ at the end of each siliceous productivity peak suggests that inputs of freshwater helped re-establish/strengthen the halocline, limiting the upwelling of nutrient-/ $\mathrm{CO}_{2}$-rich sub-surface waters and biological activity. However, with the decrease in $\delta^{18} \mathrm{O}_{\text {diatom }}$ only occurring after the initial decline in productivity, freshwater can only be acting as a secondary control in re-establishing the halocline.

Previous work has suggested a link between changes in the subarctic north-west Pacific Ocean and the Southern Ocean (Jaccard et al., 2005, 2010; Brunelle et al., 2007; Shigemitsu et al., 2007; Galbraith et al., 2008; Sigman et al., 2010).
The most viable mechanisms for synchronous changes between polar regions are temperature- and salinity-driven variations in water column density (Brunelle et al., 2007). For example a cooling of polar SST would reduce the rate of sub-surface upwelling into the photic zone (de Boer et al., 2007), lowering nutrient availability and potentially triggering the initial decline in siliceous productivity. At the same time, a decrease in SST would increase the sensitivity of the water column to subsequent changes in salinity, making the region highly vulnerable to inputs of freshwater which would strengthen the water column and inhibit productivity (Sigman et al., 2004). Additional reductions in siliceous productivity may then arise from lower North Atlantic overturning and associated deep-water incursions and upwelling in the North Pacific (Schmittner, 2005). Support for a series of events similar to this at ODP Site 882 lies with the concordant decreases at ODP Site 882 between supplied $\mathrm{Si}(\mathrm{OH})_{4} / \delta^{30} \mathrm{Si}_{\text {diatom }} /$ opal and Antarctic $(\delta \mathrm{D}) / \mathrm{NGRIP}$ $\left(\delta^{18} \mathrm{O}_{\text {ice }}\right)$ ice-core records (NGRIP, 2004; Jouzel et al., 2007) at the start of each productivity decline from ca. 118 and $89 \mathrm{kaBP}$ respectively (Fig. 3). The final switch to a low productivity system then coincides with the later decreases in $\delta^{18} \mathrm{O}_{\text {diatom }}$ at 113 and $85 \mathrm{kaBP}$, suggesting that the climatic deterioration associated with lower $\delta \mathrm{D} / \delta^{18} \mathrm{O}_{\text {ice }}$ may have fuelled the increase in precipitation and/or an advancement of regional glaciers around the North Pacific Basin that triggered the increase in freshwater input. Whilst it remains unclear what initiated either siliceous productivity peak, it can be speculated that reductions in freshwater after $100 \mathrm{kaBP}$ could have weakened the halocline and created the conditions for the second productivity bloom to eventually develop later in MIS 5b/c.

\subsection{Photic zone changes from MIS 4-5a}

Previous research has documented reduced levels of productivity in the north-west Pacific Ocean during the last glacial in response to surface water stratification (Narita et al., 2002; Jaccard et al., 2005, 2010; Brunelle et al., 2007, 2010; Shigemitsu et al., 2007; Galbraith et al., 2008; Gebhardt et al., 2008). From the latter half of MIS 5a onwards records of $\delta^{15} \mathrm{~N}_{\text {diatom }}$ and $\delta^{30} \mathrm{Si}_{\text {diatom }} / \mathrm{Si}(\mathrm{OH})_{4}$ consumption become anti-correlated (Fig. 3). Combined with a long-term shift to lower rates of $\mathrm{Si}(\mathrm{OH})_{4}$ supply and higher rates of $\mathrm{Si}(\mathrm{OH})_{4}$ consumption, this supports suggestions that changes in dust/iron inputs in the last glacial may have helped regulate the biological pump by altering the biological demand for individual nutrients (Brunelle et al., 2007, 2010; Galbraith et al., 2008; Shigemitsu et al., 2008), in this case by increasing biological uptake of silicon over nitrogen to the extent that $\mathrm{Si}(\mathrm{OH})_{4}$ consumption in MIS 4 was up to $40 \%$ higher than during MIS 5e. Elevated $\mathrm{Si}(\mathrm{OH})_{4}$ consumption may also indicate that the availability of $\mathrm{Si}(\mathrm{OH})_{4}$ rather than iron may have ultimately limited siliceous productivity over 
this interval, in line with a previous suggestion by Kienast et al. (2004).

Superimposed on a trend of low siliceous productivity during MIS 5a and MIS 4 are two small-moderate increases in opal at ca. 76-74 kaBP and ca. $70 \mathrm{kaBP}$ (Fig. 3, green shading). The increase at $70 \mathrm{kaBP}$ does not coincide with any samples analysed in this study, but the increase at 76$74 \mathrm{kaBP}$ coincides with higher $\delta^{13} \mathrm{C}_{\text {diatom, }} \delta^{30} \mathrm{Si}_{\text {diatom }}$ and $\mathrm{Si}(\mathrm{OH})_{4}$ supply/consumption (open model). Similar to before, both opal peaks culminate with a $2-3 \%$ o reduction in $\delta^{18} \mathrm{O}_{\text {diatom }}$ (Fig. 3, red shading), reiterating the role of freshwater in controlling photic zone dynamics in an era that coincides with increased monsoonal and thus precipitation variability (Sun et al., 2006; Shigemitsu et al., 2007; Zhang et al., 2009). However, whereas the earlier declines in siliceous productivity during MIS 5e and MIS 5b/c are accompanied by reductions in both $\mathrm{Si}(\mathrm{OH})_{4}$ supply and consumption, here the declines initially occur with reduced $\mathrm{Si}(\mathrm{OH})_{4}$ supply and higher rates of $\mathrm{Si}(\mathrm{OH})_{4}$ consumption. This advocates the aforementioned suggestion that the photic zone shifted to a new state from the end of MIS 5a, highlighted by further large changes in $\mathrm{Si}(\mathrm{OH})_{4}$ consumption in MIS 4 that do not coincide with a changes in siliceous productivity or $\delta^{18} \mathrm{O}_{\text {diatom }}$ (Fig. 3).

\section{Conclusions}

Results here provide evidence for significant temporal changes in the strength and efficiency of the regional softtissue biological pump from MIS 4-5e, altering the ratio of regenerated to preformed nutrients in the water column. In particular the results show evidence of an inefficient softtissue biological pump from 124 to $114 \mathrm{kaBP}$, creating the potential for the region to have played a role in maintaining the warm climate of the last interglacial through the ventilation of oceanic $\mathrm{CO}_{2}$ to the atmosphere. In addition to highlighting temporal changes in the biological pump, the data also reveal that the end of both these and other siliceous productivity fluxes over the analysed interval are linked to significant increases in freshwater input to the region, reestablishing/strengthening the halocline and limiting the subsurface supply of nutrient- and carbon-rich waters to the photic zone. However, further work is needed to resolve the source of these freshwater inputs and the mechanisms responsible for initiating the increase in siliceous productivity and $\mathrm{Si}(\mathrm{OH})_{4}$ supply to the photic zone. Finally, whilst these findings reiterate earlier work in indicating a highly dynamic and changing water column in the subarctic North Pacific Ocean during the last glacial-interglacial cycle, further work is needed to assess the spatial representativeness of these results in other sectors of the subarctic North Pacific Ocean.

\section{The Supplement related to this article is available online} at doi:10.5194/cp-11-15-2015-supplement.
Acknowledgements. Thanks are owed to Eric Galbraith and Sam Jaccard for providing information on the ODP Site 882 age model and previously published BioBa and Opal data. Funding for GEAS was provided in part by a Natural Environment Research Council (NERC) postdoctoral fellowship award (NE/F012969/1). Finally we thank two anonymous reviewers whose comments helped to improve this manuscript.

Edited by: E. McClymont

\section{References}

Abramson, L., Wirick, S., Lee, C., Jacobsen, C., and Brandes, J. A.: The use of soft $x$ ray spectromicroscopy to investigate the distribution and composition of organic matter in a diatom frustule and a biomimetic analog, Deep-Sea Res. Pt.-II, 56, 1369-1380, 2009.

Antonov, J. I., Seidov, D., Boyer, T. P., Locarnini, R. A., Mishonov, A. V., Garcia, H. E., Baranova, O. K., Zweng, M. M., and Johnson, D. R.: World Ocean Atlas 2009, Volume 2: Salinity, edited by: Levitus, S., in: NOAA Atlas NESDIS 69, US Government Printing Office, Washington DC, 184 pp., 2010.

Ayers, J. M. and Lozier, M. S.: Unraveling dynamical controls on the North Pacific carbon sink, J. Geophys. Res., 117, C01017, doi:10.1029/2011JC007368, 2012.

Banse, K. and English, D. C.: Comparing phytoplankton seasonality in the eastern and western subarctic Pacific and the western Bering sea, Prog. Oceanogr., 43, 235-288, 1999.

Barr, I. D. and Clark, C. D.: Glaciers and climate in Pacific Far NE Russia during the Last Glacial Maximum, J. Quaternary Sci., 26, 227-237, 2011.

Barr, I. D. and Clark, C. D.: Late Quaternary glaciations in Far NE Russia; combining moraines, topography and chronology to assess regional and global glaciation synchrony, Quaternary Sci. Rev., 53, 72-87, 2012.

Barr, I. D. and Solomina, O.: Pleistocene and Holocene glacier fluctuations upon the Kamchatka Peninsula, Global Planet. Change, 113, 110-120, 2014.

Bigg, G. R., Clark, C. D., and Hughes, A. L. C.: A last glacial ice sheet on the Pacific Russian coast and catastrophic change arising from coupled ice-volcanic interaction, Earth Planet. Sc. Lett., 265, 559-570, 2008.

Brandriss, M. E., O’Neil, J. R., Edlund, M. B., and Stoermer, E. F.: Oxygen isotope fractionation between diatomaceous silica and water, Geochim. Cosmochim. Ac., 62, 1119-1125, 1998.

Brunelle, B. G., Sigman, D. M., Cook, M. S., Keigwin, L. D., Haug, G. H., Plessen, B., Schettler, G., and Jaccard, S. L.: Evidence from diatom-bound nitrogen isotopes for subarctic $\mathrm{Pa}$ cific stratification during the last ice age and a link to North Pacific denitrification changes, Paleoceanography, 22, PA1215, doi:10.1029/2005PA001205, 2007.

Brunelle, B. G., Sigman, D. M., Jaccard, S. L., Keigwin, L. D., Plessen, B., Schettler, G., Cook, M. S., and Haug, G. H.; Glacial/interglacial changes in nutrient supply and stratification in the western subarctic North Pacific since the penultimate glacial maximum, Quaternary Sci. Rev., 29, 2579-2590, 2010. 
Cassar, N., Laws, E. A., Bidigare, R. R., and Popp, B. N.: Bicarbonate uptake by Southern Ocean phytoplankton, Global Biogeochem. Cy., 18, GB2003, doi:10.1029/2003GB002116, 2004.

Cassar, N., Laws, E. A., and Popp, B. N.: Carbon isotopic fractionation by the marine diatom Phaeodactylum tricornutum under nutrient- and light-limited growth condition, Geochim. Cosmochim. Ac., 70, 5323-5335, 2006.

Chierici, M., Fransson, A., and Nojiri, Y.: Biogeochemical processes as drivers of surface $f \mathrm{CO}_{2}$ in contrasting provinces in the subarctic North Pacific Ocean, Global Biogeochem. Cy., 20, GB1009, doi:10.1029/2004GB002356, 2006.

Crespin, J., Sylvestre, F., Alexandre, A., Sonzogni, C., Pailles, C., and Perga, M.-E.: Re-examination of the temperature-dependent relationship between $\delta^{18} \mathrm{O}_{\text {diatom }}$ and $\delta^{18} \mathrm{O}_{\text {lake water }}$ and implications for paleoclimate inferences, J. Paleolimnol., 44, 547-557, 2010.

de Boer, A. M., Sigman, D. M., Toggweiler, J. R., and Russell, J. L.: Effect of global ocean temperature change on deep ocean ventilation, Paleoceanography, 22, PA2210, doi:10.1029/2005pa001242, 2007.

De La Rocha, C. L.: Opal-based isotopic proxies of paleoenvironmental conditions, Global Biogeochem. Cy., 20, GB4S09, doi:10.1029/2005GB002664, 2006.

De La Rocha, C. L and Bickle, M. J.: Sensitivity of silicon isotopes to whole-ocean changes in the silica cycle, Mar. Geol., 271, 267282, 2005.

De La Rocha, C. L., Brzezinski, M. A., and DeNiro, M. J.: Fractionation of silicon isotopes by marine diatoms during biogenic silica formation, Geochim. Cosmochim. Ac., 61, 5051-5056, 1997.

Dodd, J. P. and Sharp, Z. D.: A laser fluorination method for oxygen isotope analysis of biogenic silica and a new oxygen isotope calibration of modern diatoms in freshwater environments, Geochim. Cosmochim. Ac., 74, 1381-1390, 2010.

Emile-Geay, J., Cane, M. A., Naik, N., Seager, R., Clement, A. C., and van Green, A.: Warren revisited: atmospheric freshwater fluxes and "Why is no deep water formed in the North Pacific", J. Geophys. Res., 108, 3178, doi:10.1029/2001JC001058, 2003.

Fischer, H., Schmitt, J., Lüthi, D., Stocker, T. F., Tschumi, T., Parekh, P., Joos, F., Köhler, P., Völker, C., Gersonde, R., Barbante, C., Le Floch, M., Raynaud, D., and Wolff, E.: The role of Southern Ocean processes in orbital and millennial $\mathrm{CO}_{2}$ variations - a synthesis, Quaternary Sci. Rev., 29, 193-205, 2010.

Galbraith, E. D., Jaccard, S. L., Pedersen, T. F., Sigman, D. M., Haug, G. H., Cook, M., Southon, J. R., and Francois, R.: Carbon dioxide release from the North Pacific abyss during the last deglaciation, Nature, 449, 890-894, 2007.

Galbraith, E. D., Kienast, M., Jaccard, S. L., Pedersen, T. F., Brunelle, B. G., Sigman, D. M., and Kiefer, T.: Consistent relationship between global climate and surface nitrate utilization in the western subarctic Pacific throughout the last $500 \mathrm{ka}$, Paleoceanography, 23, PA2212, doi:10.1029/2007PA001518, 2008.

Gebhardt, H., Sarnthein, M., Grootes, P. M., Kiefer, T., Kuehn, H., Schmieder, F., and Rohl, U.: Paleonutrient and productivity records from the subarctic North Pacific for Pleistocene glacial terminations I to V, Paleoceanography, 23, PA4212, doi:10.1029/2007PA001513, 2008.

Gebbie, G. and Huybers, P.: How is the ocean filled?, Geophys. Res. Lett., 38, L06604, doi:10.1029/2011GL046769, 2011.
Harrison, P. J., Boyd, P. W., Varela, D. E., Takeda, S., Shiomoto, A., and Odate, T.: Comparison of factors controlling phytoplankton productivity in the NE and NW subarctic Pacific gyres, Prog. Oceanogr., 43, 205-234, 1999.

Haug, G. H. and Sigman, D. M.: Polar twins, Nat. Geosci., 2, 91-92, 2009.

Haug, G. H., Ganopolski, A., Sigman, D. M., Rosell-Mele, A., Swann, G. E. A., Tiedemann, R., Jaccard, S, Bollmann, J., Maslin, M. A., Leng, M. J., and Eglinton, G.: North Pacific seasonality and the glaciation of North America 2.7 million years ago, Nature, 433, 821-825, 2005.

Hecky, R. E., Mopper, K., Kilham, P., and Degens, E. T.: The amino acid and sugar composition of diatom cell-walls, Mar. Biol., 19, 323-331, 1973.

Hillebrand, H., Dürselen, C.-D., Kirschtel, D., Pollingher, U., and Zohary, T.: Biovolume calculation for pelagic and benthic microalgae, J. Phycol., 35, 403-424, 1999.

Honda, M. C., Imai, K., Nojiri, Y., Hoshi, F., Sugawarad, T., and Kusakabe, M.: The biological pump in the northwestern North Pacific based on fluxes and major components of particulate matter obtained by sediment-trap experiments (1997-2000), DeepSea Res. Pt.-II, 49, 5595-5625, 2002.

Hsu, S.-C., Huh, C.-A., Lin, C.-Y., Chen, W.-N., Mahowald, N. M., Liu, S.-C., Chou, C. C. K., Liang, M.-C., Tsai, C.-J., Lin, F.J., Chen, J.-P., and Huang, Y.-T.: Dust transport from non-East Asian sources to the North Pacific, Geophys. Res. Lett., 39, L12804, doi:10.1029/2012GL051962, 2012.

Hurrell, E. R., Barker, P. A., Leng, M. J, Vane, C. H., Wynn, P., Kendrick, C. P., Verschuren, D., and Street-Perrott, F.: Developing a methodology for carbon isotope analysis of lacustrine diatoms, Rapid Commun. Mass Sp., 25, 1567-1574, 2011.

Jaccard, S. L., Haug, G. H., Sigman, D. M., Pedersen, T. F., Thierstein, H. R., and Röhl, U.: Glacial/interglacial changes in subarctic North Pacific stratification, Science, 308, 1003-1006, 2005.

Jaccard, S. L., Galbraith, E. D., Sigman, D. M., Haug, G. H., Francois, R., Pedersen, T. F., Dulski, P., and Thierstein, H. R.: Subarctic Pacific evidence for a glacial deepening of the oceanic respired carbon pool, Earth Planet. Sc. Lett., 277, 156-165, 2009.

Jaccard, S. L., Galbraith, E. D., Sigman, D. M., and Haug, G. H.: A pervasive link between Antarctic ice core and subarctic Pacific sediment records over the past 800 kyrs, Quaternary Sci. Rev., 29, 206-212, 2010.

Jacot des Combes, H., Esper, O., De La Rocha, C. L., Abelmann, A., Gersonde, R., Yam, R., and Shemesh, A.: Diatom $\delta^{13} \mathrm{C}, \delta^{15} \mathrm{~N}$, and $\mathrm{C} / \mathrm{N}$ since the Last Glacial Maximum in the Southern Ocean: potential impact of species composition, Paleoceanography, 23, PA4209, doi:10.1029/2008PA001589, 2008.

Jouzel, J., Masson-Delmotte, V., Cattani, O., Dreyfus, G., Falourd, S., Hoffmann, G., Minster, B., Nouet, J., Barnola, J. M., Chappellaz, J., Fischer, H., Gallet, J. C., Johnsen, S., Leuenberger, M., Loulergue, L., Luethi, D., Oerter, H., Parrenin, F., Raisbeck, G., Raynaud, D., Schilt, A., Schwander, J., Selmo, E., Souchez, R., Spahni, R., Stauffer, B., Steffensen, J. P., Stenni, B., Stocker, T. F., Tison, J. L., Werner, M., and Wolff, E. W.: Orbital and millennial Antarctic climate variability over the past 800000 years, Science, 371, 793-796, 2007.

Kienast, S. S., Hendy, I. L., Crusius, J., Pedersen, T. F., and Calvert, S. E.: Export production in the subarctic North Pa- 
cific over the last 800 kyrs: no evidence for iron fertilization?, J. Oceanogr., 60, 189-203, 2004.

Kohfeld, K. E. and Chase, Z.: Controls on deglacial changes in biogenic fluxes in the North Pacific Ocean, Quaternary Sci. Rev., 30, 3350-3363, 2011.

Kröger, N., Deutzmann, R., and Sumper, M.: Polycationic peptides from diatom biosilica that direct silica nanosphere formation, Science, 286, 1129-1132, 1999.

Lam, P. J. and Bishop, J. K. B.: The paleoclimatic record provided by eolian deposition in the deep-sea: the geologic history of wind, Geophys. Res. Lett., 35, L07608, doi:10.1029/2008GL033294, 2008.

Lam, P. J., Robinson, L. F., Blusztajn, J., Li, C., Cook, M. S., McManus, J. F., and Keigwin, L. D.: Transient stratification as the cause of the North Pacific productivity spike during deglaciation, Nat. Geosci., 6, 622-626, 2013.

Laws, E. A., Popp, B. N., Bidigare, R. R., Kennicutt, M. C., and Macko, S. A.: Dependence of phytoplankton carbon isotopic composition on growth rate and $\left(\mathrm{CO}_{2}\right)_{\text {aq }}$ : theoretical considerations and experimental results, Geochim. Cosmochim. Ac., 59, 1131-1138, 1995.

Laws, E. A., Bidigare, R. R., and Popp, N. B.: Effect of growth rate and $\mathrm{CO}_{2}$ concentration on carbon isotope fractionation by the marine diatom Phaeodactylum tricornutum, Limnol. Ocanogr., 42, 1552-1560, 1997.

Laws, E. A., Popp, B. N., Cassar, N., and Tanimoto, J.: ${ }^{13}$ C discrimination patterns in oceanic phytoplankton: likely influence of $\mathrm{CO}_{2}$ concentrating mechanisms, and implications for palaeoreconstructions, Funct. Plant Biol., 29, 323-333, 2002.

LeGrande, A. N. and Schmidt, G. A.: Global gridded data set of the oxygen isotopic composition in seawater, Geophys. Res. Lett., 33, L12604, doi:10.1029/2006GL026011, 2006.

Leng, M. J. and Sloane, H. J.: Combined oxygen and silicon isotope analysis of biogenic silica, J. Quaternary Sci., 23, 313-319, 2008.

Locarnini, R. A., Mishonov, A. V., Antonov, J. I., Boyer, T. P., Garcia, H. E., Baranova, O. K., Zweng, M. M., and Johnson, D. R.: World Ocean Atlas 2009, Volume 1: Temperature, in: NOAA Atlas NESDIS 68, edited by: Levitus, S., US Government Printing Office, Washington DC, 184 pp., 2010.

Mann, D. G.: The species concept in diatoms, Phycologia, 38, 437495, 1999.

Marinov, I., Follows, M., Gnanadesikan, A., Sarmiento, J. L., and Slater, R. D.: How does ocean biology affect atmospheric $p \mathrm{CO}_{2}$ ? Theory and models, J. Geophys. Res., 113, C07032, doi:10.1029/2007JC004598, 2008.

Martin, C. L. and Tortell, P. D.: Bicarbonate transport and extracellular carbonic anhydrase activity in Bering Sea phytoplankton assemblages: results from isotope disequilibrium experiments, Limnol. Oceanogr., 51, 2111-2121, 2006.

Martin, C. L. and Tortell, P. D.: Bicarbonate transport and extracellular carbonic anhydrase in marine diatoms, Physiol. Plantarum, 133, 106-116, 2008.

Martínez-Garcia, A., Rosell-Melé, A., McClymont, E. L., Gersonde, R., and Haug, G. H.: Subpolar link to the emergence of the modern equatorial Pacific cold tongue, Science, 328, 15501553, 2010.

Menviel, L., Timmermann, A., Timm, O., Mouchet, A., AbeOuchi, A., Chikamoto, M. O., Harada, N., Ohgaito, R., and Okazaki, Y.: Removing the North Pacific halocline: effects on global climate, ocean circulation and the carbon cycle, Deep-Sea Res. Pt.-II, 61-64, 106-113, 2012.

Milligan, A. J., Varela, D. E., Brzezinski, M. A., and Morel, F. M. M.; Dynamics of silicon metabolism and silicon isotopic discrimination in a marine diatom as a function of $p \mathrm{CO}_{2}$, Limnol. Oceanogr., 49, 322-329, 2004.

Moschen, R., Lücke, A., and Schleser, G.: Sensitivity of biogenic silica oxygen isotopes to changes in surface water temperature and palaeoclimatology, Geophys. Res. Lett., 32, L07708, doi:10.1029/2004GL022167, 2005.

Narita, H., Sato, M., Tsunogai, S., Murayama, M., Ikehara, M., Nakatsuka, T., Wakatsuchi, M., Harada, N., and Ujiié, Y.: Biogenic opal indicating less productive northwestern North Pacific during the glacial ages, Geophys. Res. Lett., 29, 1732, doi:10.1029/2001GL014320, 2002.

Nelson, D. M., Tréguer, P., Brzezinski, M. A., Leynaert, A., and Quéguiner, B.: Production and dissolution of biogenic silica in the ocean: revised global estimates, comparison with regional data and relationship to biogenic sedimentation, Global Biogeochem. Cy., 9, 359-372, 1995.

North Greenland Ice Core Project members: High-resolution record of Northern Hemisphere climate extending into the last interglacial period, Nature, 431, 147-151, 2004.

Nie, J., King, J., Liu, Z., Clemens, S., Prell, W., and Fang, X.: Surface-water freshening: a cause for the onset of North Pacific stratification from 2.75 Ma onward?, Global Planet. Change, 64, 49-52, 2008.

Nishioka, J., Ono, T., Saito, H., Nakatsuka, T., Takeda, S., Yoshimura, T., Suzuki, K., Kuma, K., Nakabayashi, S., Tsumune, D., Mitsudera, H., Johnson, W. K., and Tsuda, A.: Iron supply to the western subarctic Pacific: importance of iron export from the Sea of Okhotsk, J. Geophys. Res., 112, C10012, doi:10.1029/2006JC004055, 2007.

Nürnberg, D., Dethleff, D., Tiedemann, R., Kaiser, A., and Gorbarenko, S. A.: Okhotsk Sea ice coverage and Kamchatka glaciation over the last $350 \mathrm{ka}$ - evidence from ice-rafted debris and planktonic $\delta^{18} \mathrm{O}$, Palaeogeogr. Palaeocl., 310, 191-205, 2011.

Onodera, J., Takahashi, K., and Honda, M. C.: Pelagic and coastal diatom fluxes and the environmental changes in the northwestern North Pacific during 1997-2000, Deep-Sea Res. Pt.-II, 52, 2218 2239, 2005.

Pichevin, L. E., Reynolds, B. C., Ganeshram, R. S., Cacho, I., Pena, L., Keefe, K., and Ellam, R. M.: Enhanced carbon pump inferred from relaxation of nutrient limitation in the glacial ocean, Nature, 459, 1114-1118, 2009.

Popp, B. N., Laws, E. A., Bidigare, R. R., Dore, J. E., Hanson, K. L., and Wakeham, S. G.: Effect of phytoplankton cell geometry on carbon isotopic fractionation, Geochim. Cosmochim. Ac., 62, 69-77, 1998.

Rae, J. W. B., Sarnthein, M., Foster, G. L., Ridgwell, A., Grootes, P. M., and Elliott, T.: Deep water formation in the North Pacific and deglacial $\mathrm{CO}_{2}$ rise, Paleoceanography, 29, 645-667, 2014.

Rau, G. H., Riebeseell, U., and Wolf-Gladrow, D.: A model of photosynthetic ${ }^{13} \mathrm{C}$ fractionation by marine phytoplankton based on diffusive molecular $\mathrm{CO}_{2}$ uptake, Mar. Ecol.-Prog. Ser., 133, 275285, 1996. 
Rau, G. H., Riebesell, U., and Wolf-Gladrow, D.: $\mathrm{CO}_{2}$ aq-dependent photosynthetic ${ }^{13} \mathrm{C}$ fractionation in the ocean: a model versus measurements, Global Biogeochem. Cy., 11, 267-278, 1997.

Rau, G. H., Chavez, F. P., and Friederich, G. E.: Plankton ${ }^{13} \mathrm{C} /{ }^{12} \mathrm{C}$ variations in Monterey Bay, California: evidence of non-diffusive inorganic carbon uptake by phytoplankton in an upwelling environment, Deep-Sea Res. Pt.-I, 48, 79-94, 2001.

Reinfelder, J. R., Kraepiel, A. M. L., and Morel, F. M. M.: Unicellular C4 photosynthesis in a marine diatom, Nature, 407, 996-999, 2000.

Reynolds, B. C., Frank, M., and Halliday, A. N.: Silicon isotope fractionation during nutrient utilization in the North Pacific, Earth Planet. Sc. Lett., 244, 431-443, 2006.

Sarnthein, M., Gebhardt, H., Kiefer, T., Kucera, M., Cook, M., and Erlenkeuser, H.: Mid Holocene origin of the sea-surface salinity low in the subarctic North Pacific, Quaternary Sci. Rev., 23, 2089-2099, 2004.

Schmittner, A.: Decline of the marine ecosystem caused by a reduction in the Atlantic overturning circulation, Nature, 434, 628633,2005

Serno, S., Winckler, G., Anderson, R. F., Hayes, C. T., Ren, H., Gersonde, R., and Haug, G. H.: Using the natural spatial pattern of marine productivity in the Subarctic North Pacific to evaluate paleoproductivity proxies, Paleoceanography, 29, 438-453, 2014.

Shigemitsu, M., Narita, H., Watanabe, Y. W., Harada, N., and Tsunogai, S.: Ba, Si, U, Al, Sc, La, Th, C and ${ }^{13} \mathrm{C} /{ }^{12} \mathrm{C}$ in a sediment core in the western subarctic Pacific as proxies of past biological production, Mar. Chem., 106, 442-455, 2007.

Shigemitsu, M., Watanabe, Y. W., and Narita, H.: Time variations of $\delta^{15} \mathrm{~N}$ of organic nitrogen in deep western subarctic Pacific sediment over the last $145 \mathrm{ka}$, Geochem. Geophy. Geosy., 9, Q10012, doi:10.1029/2008GC001999, 2008.

Shigemitsu, M., Okunishi, T., Nishioka, J., Sumata, H., Hashioka, T., Aita, M. N., Smith, S. L., Yoshie, N., Okada, N., and Yamanaka, Y.: Development of a one-dimensional ecosystem model including the iron cycle applied to the Oyashio region, western subarctic Pacific, J. Geophys. Res., 117, C06021, doi:10.1029/2011JC007689, 2012.

Sigman, D. M., Jaccard, S. L., and Haug, G. H.: Polar ocean stratification in a cold climate, Nature, 428, 59-63, 2004.

Sigman, D. M., Hain, M. P., and Haug, G. H.: The polar ocean and glacial cycles in atmospheric $\mathrm{CO}_{2}$ concentration, Nature, 47-55, 2010.

Sültemeyer, D., Schmidt, C., and Fock, H. P.: Carbonic anhydrases in higher plants and aquatic microorganisms, Physiol. Plantarum, 88, 179-190, 1993.

Sumper, M. and Kröger, N.: Silica formation in diatoms: the function of long-chain polyamines and silaffins, J. Mater. Chem., 14, 2059-2065, 2004.

Sun, Y., Clemens, S. C., An, Z., and Yu, Z.: Astronomical timescale and palaeoclimatic implication of stacked 3.6-Myr monsoon records from the Chinese Loess Plateau, Quaternary Sci. Rev., 25, 33-48, 2006.
Swann, G. E. A.: Salinity changes in the North West Pacific Ocean during the late Pliocene/early Quaternary from $2.73 \mathrm{Ma}$ to 2.53 Ma, Earth Planet. Sc. Lett., 297, 332-338, 2010.

Swann, G. E. A. and Leng, M. J.: A review of diatom $\delta^{18} \mathrm{O}$ in palaeoceanography, Quaternary Sci. Rev., 28, 384-398, 2009.

Swann, G. E. A., Maslin, M. A., Leng, M. J., Sloane, H. J., and Haug, G. H.: Diatom $\delta^{18} \mathrm{O}$ evidence for the development of the modern halocline system in the subarctic northwest Pacific at the onset of major Northern Hemisphere glaciation, Paleoceanography, 21, PA1009, doi:10.1029/2005PA001147, 2006.

Swann, G. E. A., Leng, M. J., Sloane, H. J., and Maslin, M. A.: Isotope offsets in marine diatom $\delta^{18} \mathrm{O}$ over the last $200 \mathrm{ka}, \mathrm{J}$. Quaternary Sci., 23, 389-400, 2008.

Swift, D. M. and Wheeler, A. P.: Evidence of an organic matrix from diatom biosilica, J. Phycol., 28, 202-290, 1992.

Takahashi, K.: Seasonal fluxes of pelagic diatoms in the subarctic Pacific, 1982-1983, Deep-Sea Res., 33, 1225-1251, 1986.

Takahashi, K., Hisamichi, K., Yanada, M., and Maita, Y.: Seasonal changes of marine phytoplankton productivity: a sediment trap study, Kaiyo Monthly, 10, 109-115, 1996.

Takahashi, T., Sutherland, S. C., Feely, R. A., and Wanninkhof, R.: Decadal change of the surface water $p \mathrm{CO}_{2}$ in the North Pacific: a synthesis of 35 years of observations, J. Geophys. Res., 111, C07S05, doi:10.1029/2005JC003074, 2006.

Tortell, P. D. and Morel, F. M. M.: Sources of inorganic carbon for phytoplankton in the eastern Subtropical and equatorial Pacific Ocean, Limnol. Oceanogr., 47, 1012-1022, 2002.

Tortell, P. D., Reinfelder, J. R., and Morel, F. M. M.: Active uptake of bicarbonate by diatoms, Nature, 390, 243-244, 1997.

Tortell, P. D., Martin, C. L., and Corkum, M. E.: Inorganic carbon uptake and intracellular assimilation by subarctic Pacific phytoplankton assemblages, Limnol. Oceanogr., 51, 2102-2110, 2006.

Tortell, P. D., Payne, C., Gueguen, C., Strzepek, R. F., Boyd, P. W., and Rost, B.: Inorganic carbon uptake by Southern Ocean phytoplankton, Limnol. Oceanogr., 45, 1485-1500, 2008.

Tsuda, A., Takeda, S., Saito, H., Nishioka, J., Nojiri, Y., Kudo, I., Kiyosawa, H., Shiomoto, A., Imai, K., Ono, T., Shimamoto, A., Tsumune, D., Yoshimura, T., Aono, T., Hinuma, A., Kinugasa, M., Suzuki, K., Sohrin, Y., Noiri, Y., Tani, H., Deguchi, Y., Tsurushima, N., Ogawa, H., Fukami, K., Kuma, K., and Saino, T.: A mesoscale iron enrichment in the Western Subarctic Pacific induces a large centric diatom bloom, Science, 300, 958-961, 2003.

Whitney, F. A., Bograd, S. J., and Ono, T.: Nutrient enrichment of the subarctic Pacific Ocean pycnocline, Geophys. Res. Lett., 40, 2200-2205, 2013.

Yuan, W. and Zhang, J.: High correlations between Asian dust events and biological productivity in the western North Pacific, Geophys. Res. Lett., 33, L07603, doi:10.1029/2005GL025174, 2006.

Zhang, Y. G., Ji, J., Balsam, W., Liu, L., and Chen, J.: Mid-Pliocene Asian monsoon intensification and the onset of Northern Hemisphere glaciation, Geology, 37, 599-602, 2009. 